\title{
Correction to: Impact of Bariatric Surgery on Clinical, Biochemical, and Hormonal Parameters in Women with Polycystic Ovary Syndrome (PCOS)
}

\author{
Devender Singh $^{1} \cdot$ Kirit Arumalla $^{1} \cdot$ Sandeep Aggarwal ${ }^{1} \cdot$ Vitish Singla $^{1} \cdot$ Mohd Ashraf Ganie $^{2} \cdot$ Neena $^{\text {Malhotra }}{ }^{3}$
}

Published online: 27 March 2020

(C) Springer Science+Business Media, LLC, part of Springer Nature 2020

\section{Correction to: Obesity Surgery.}

https://doi.org/10.1007/s11695-020-04487-3

In the original article the name of author Mohd Ashraf Ganie was presented incorrectly. It is correct here.

Publisher's Note Springer Nature remains neutral with regard to jurisdictional claims in published maps and institutional affiliations.

The online version of the original article can be found at https://doi.org/ 10.1007/s11695-020-04487-3

Sandeep Aggarwal

sandeep_aiims@yahoo.co.in

Devender Singh

devinderkuntal@gmail.com

Kirit Arumalla

kiritarumalla90@gmail.com

Vitish Singla

vitishaiims@gmail.com

Mohd Ashraf Ganie

ashraf.endo@gmail.com
Neena Malhotra

malhotraneena@yahoo.com

1 Department of Surgical Disciplines, All India Institute of Medical Sciences, Room no, New Delhi 5034, India

2 Department of Endocrinology, All India Institute of Medical Sciences, New Delhi, India

3 Department of Gynaecology, All India Institute of Medical Sciences, New Delhi, India 